\title{
Геохимические особенности метасоматитов харбейского комплекса (Полярный Урал)
}

\author{
Уляшева Н.С. \\ Институт геологии Коми НЦ УрО РАН, Сыктывкар,nsulasheva@geo.komisc.ru
}

\begin{abstract}
Аннотация. Изучены петрогеохимические особенности пород харбейского комплекса по руч. Скалистому, представленных гранат-барруазитовыми амфиболитами и метасоматитами - клиноцоизит-хлоритмусковит-альбит-амфиболовыми сланцами, эпидотизированными и окварцованными образованиями, к которым приурочены минералы золота, серебра и палладия. Метасоматиты характеризуются повышенными содержаниями крупноионных литофилов - калия, рубидия, бария; высокозарядных элементов - тантала, свинца, ниобия и ЛРЗЭ по сравнению с амфиболитами. Из пород выносились тяжелые редкоземельные элементы. Для эпидотизированных пород характерно повышенное содержание циркония, хрома и стронция, а для окварцованных сульфидизированных пород - циркония, меди, цинка, молибдена, тория и урана. Учитывая геохимические особенности окварцованных пород, можно предположить, что кварцевые жилы и прожилки сформировались за счет растворов, отделившихся от магм кислого состава.
\end{abstract}

Ключевые слова: харбейский комплекс, амфиболиты, метасоматиты, химический состав.

\section{Geochemical features of metasomatites of the Harbey complex (Polar Urals)}

\author{
Ulyasheva N.S. \\ Institute of geology of Komi SC UB Ras, Syktyvkar,nsulasheva@geo.komisc.ru
}

\begin{abstract}
The petrogeochemical features of the rocks of the Harbey complex along the Skalisty Stream were studied. They are represented by garnet-barruasite amphibolites and metasomatites: clinocoisite-chlorite-muscovitealbite-amphibole schists, epidotized and quartzous rock formations. Sulfides and minerals of gold, silver and palladium are associated with metasomatites. Metasomatites are characterized by higher contents of large-ion lithophiles potassium, rubidium, barium, and highly charged elements - tantalum, lead, niobium, and LREE compared with amphibolites. Heavy rare earth elements were carried out from the rocks. Epidotized rocks are characterized by high levels of zirconium and strontium. In quartzous sulfidized rocks, the contents of zirconium, copper, zinc, molybdenum, thorium and uranium increase. Considering the geochemical features of quartzous rocks, it can be assumed that quartz veins and veins were formed due to solutions separated from magmas of acidic composition.
\end{abstract}

Key words: Harbey complex, amphibolites, metasomatites, chemical composition.

\section{Введение}

Харбейский метаморфический комплекс расположен в восточной части западной тектонической зоны Полярного Урала в пределах одноименного блока и сложен различными гнейсами и амфиболитами раннепротерозойского возраста (Пыстина, Пыстин, 2002; Душин и др., 2007; Уляшева, Ронкин, 2014). В зонах разломов и надвигов по этим породам развиваются метасоматиты - пропилиты, березиты, альбититы, к которым приурочены пункты золото-сульфидной и золото-медной минерализаций редкоземельно-редкометалльной и золото-сульфидно-кварцевой формаций (Душин и др., 2014).

Изучены породы харбейского метаморфического комплекса по руч. Скалистому, где они представлены в различной степени измененными амфиболитами. Рассматриваемые образования деформированы, смяты в складки и пересекаются кварцевыми, кальцитовыми, хлорит-кальцитовыми прожилками и кварцевыми жилами. В них обнаружены минералы золота, серебра и палладия - относительно низкопробное золото, ртутьсодержащий электрум, самородное серебро, меринскиит и т.д., ассоциирующие с сульфидами, теллуридами и селенидами (Уляшева, 2019).

Целью работы является изучение петрографических и петрогеохимических особенностей пород харбейского комплекса по руч. Скалистому. 


\section{Результаты и обсуждение}

Взаимоотношения породообразующих минералов и последовательность формирования минеральных парагенезисов в породах харбейского комплекса по руч. Скалистому наблюдались под поляризационным микроскопом в шлифах. Рудные минералы изучались на сканирующем электронном микроскопе Tescan Vega 3 LMH с энергодисперсионной приставкой Instruments X-Max (аналитики Шуйский А. С., Тропников Е.). Содержания породообразующих оксидов пород получены с помощью метода мокрой химии и комплексного метода мокрой химии и рентгенофлуоресцентного анализов. Содержания редких и редкоземельных элементов определялись с помощью массспектрометра с ионизацией в индуктивно связанной плазме (ICP-MS). Все исследования проводились в Институте геологии Коми НЦ РАН в ЦКП «Геонаука».

Петрографическое и микрозондовое изучение пород показало, что они представлены слабо измененными амфиболитами, а также сланцами, окварцованными и эпидотизированными образованиями, сформировавшимися по амфиболитам.

Слабо измененные амфиболиты имеют сланцеватую текстуру, порфиробластовую и гранонематобластовую структуру и состоят из амфибола - барруазита (50-70 \%), альбита (до $20 \%$ ), клиноцоизита (до $10 \%$ ), хлорита (до 5 \%), граната (1-3 \%), мусковита (до 3 \%) и кварца (до $1 \%)$ ). Акцессорные минералы представлены цирконом, титанитом и апатитом, рудные - магнетитом и пиритом.

В сланцах основными минералами являются хлорит, мусковит, альбит, актинолит, магнезиальная роговая обманка, кварц, клиноцоизит, барруазит, гранат, кальцит и калиевый полевой шпат, содержащиеся в разных пропорциях. Наиболее ранними минералами являются барруазит и гранат, унаследованные от амфиболитов. Акцессорные минералы представлены титанитом, цирконом, баритом и монацитом. В этих породах наблюдается вкрапленная минерализация пирита (до 3 \%) и редкие выделения пентландита, пирротина, халькопирита, молибденита, клаусталит-галенита, мелонита, мелонит-меринскиита, акантита, гессита и самородного серебра.

Процессы окварцевания наблюдаются в амфиболитах и сланцах. Кварц образует прожилки и линзообразные выделения, часто приуроченные к осветленным прослоям сланцев, где основными минералами являются ранний кварц, альбит, клиноцоизит и хлорит. В окварцованных образованиях встречается вкрапленная и прожилково-вкрапленная минерализация пирита (до 10 \%) и редкие зерна халькопирита, пирротина, галенита, сфалерита, борнита, хромферрида, золота, акантита, гессита, акантит-гессита, акантит-наумманнит-гессита и самородного серебра.

Преимущественно эпидотовые породы встречаются в виде будин и обособлений среди амфиболитов и сланцев и имеют массивную текстуру. По минеральному составу можно выделить мусковит-хлорит-клиноцоизитовые и хлорит-кварц-клиноцоизитовые разновидности. Они пересекаются мусковитовыми, кварцевыми, хлоритовыми, кварц-кальцит-хлоритовыми, кальцитовыми и кварц-кальцитовыми прожилками. В мусковит-хлорит-клиноцоизитовых породах, пересекающихся кварцевыми прожилками, наблюдается вкрапленная минерализация пирита (до 3 \%) и редкие образования борнита, молибденита, халькопирита, ртутьсодержащего электрума, золота, акантита, акантитгессита, наумманит-акантита, гессита и самородного серебра. В хлорит-кварц-клиноцоизитовых породах с пиритом ассоциируются клаусталит-галенит, мелонит-меринскиит и гессит.

Изучение химического состава амфиболитов и сланцев показало, что в клиноцоизит-хлоритмусковит-альбит-амфиболовых породах наблюдаются повышенные содержания глинозема, калия и натрия по сравнению с амфиболитами (рис. 1). В них увеличивается количество рубидия, ниобия, бария, легких редкоземельных элементов, тантала, а в некоторых разновидностях сланцев - свинца и тория, и уменьшается содержание титана, окисного железа, кальция и тяжелых редкоземельных элементов (рис. 1, 2).

Окварцевание сопровождается повышением в породах кремнезема, марганца, меди, рубидия, циркония, ниобия, молибдена, бария, цинка, свинца, легких редкоземельных элементов, тантала и тория и понижением окисного железа, кальция, натрия и тяжелых редкоземельных элементов (рис. 1, 2).

Преимущественно клиноцоизитовые породы характеризуются повышенным количеством кальция, двуокиси углерода, стронция, циркония, легких редкоземельных элементов, гафния, тан- 
тала, свинца и пониженными содержаниями закисного железа, марганца, магния, натрия, лития и бериллия и тяжелых редкоземельных элементов относительно амфиболита. В некоторых эпидозитах наблюдается повышенное количество хрома, рубидия, бария, тория и урана $($ рис. 1,2$)$.

\section{Выводы}

Среди пород харбейского комплекса по руч. Скалистому распространены слабо измененные гранат-барруазитовые амфиболиты и метасоматиты по амфиболитам: клиноцоизит-хлорит-мусковитальбит-амфиболовые сланцы, мусковит-хлорит-клиноцоизитовые, хлорит-кварц-клиноцоизитовые и окварцованные породы. К метасоматитам приурочены сульфиды, ассоциирующие с минералами золота, серебра и палладия.

Во всех рассматриваемых типах метасоматитов наблюдаются повышенные содержания крупноионных литофилов - калия, рубидия, бария и высокозарядных элементов - тантала, свинца, ниобия и ЛРЗЭ по сравнению с амфиболитами. При этом из пород выносились тяжелые редкоземельные элементы. Кроме того, для эпидотизированных пород характерно повышенное содержание циркония и стронция, а для окварцованных сульфидизированных пород - циркония, меди, цинка, молибдена, тория и урана. Увеличение содержания кремнезема, калия, тория и урана в окварцованных породах может указывать на то, что кварцевые жилы и прожилки сформировались из растворов, отделившихся от магматических расплавов кислого состава.

Клиноцоизит-хлорит-мусковитальбит-амфиболовые породы

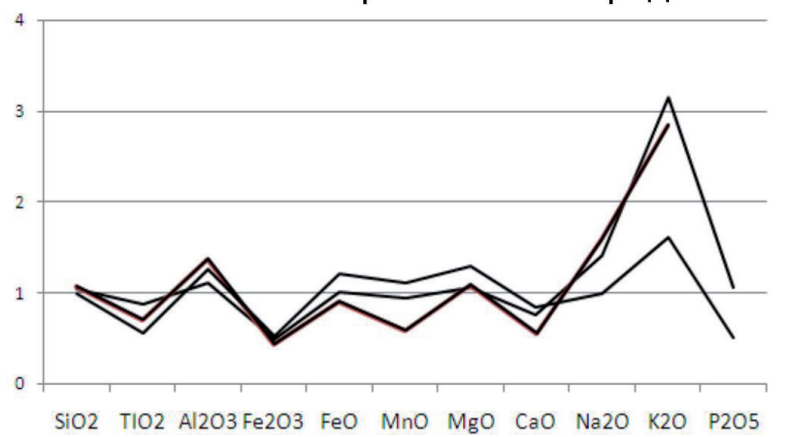

Окварцованные породы

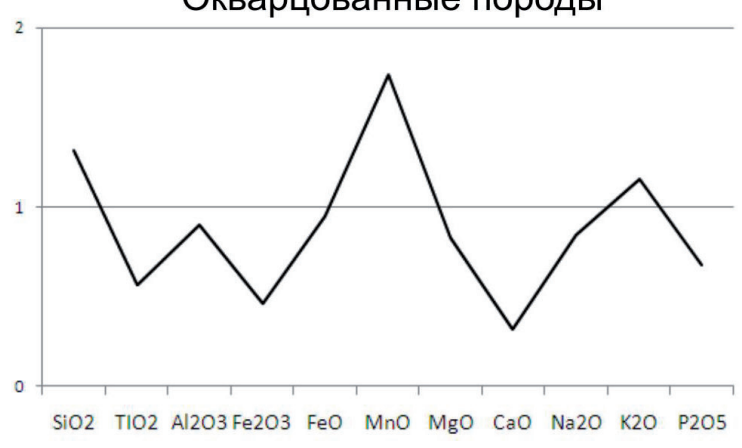

Клиноцоизитовые породы

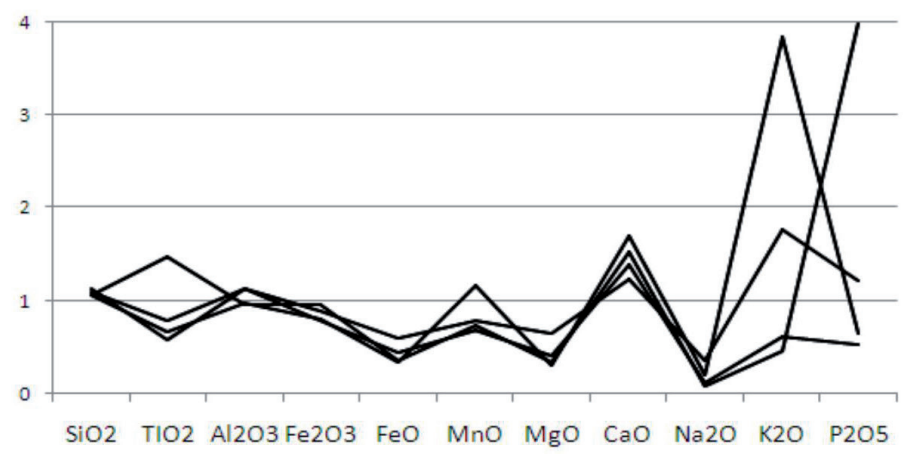

Рис. 1. Содержания породообразующих оксидов в метасоматитах харбейского комплекса, нормализованные относительно содержаний этих компонентов в амфиболите.

Fig. 1. The content of rock-forming oxides in the metasomatites of the Harbey complex normalized to the contents of these components in amphibolite. 


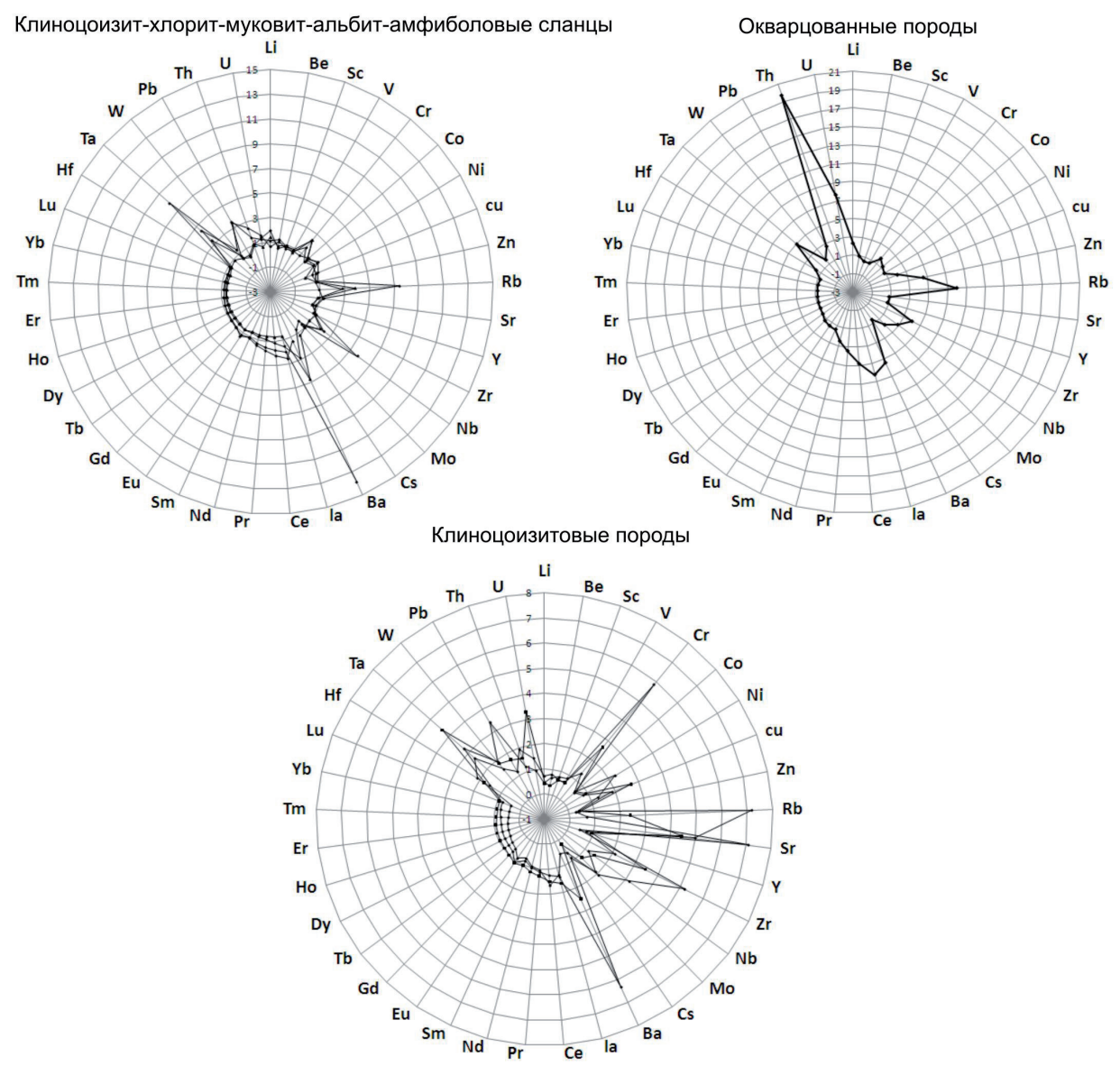

Рис. 2. Содержания редких и редкоземельных элементов в метасоматитах харбейского комплекса, нормализованные на состав амфиболита.

Fig. 2. The contents of rare and rare earth elements in the metasomatites of the Harbey complex normalized to the composition of the amphibolites.

\section{Литература}

1. Душин В.А., Сердюкова О.П., Малюгин А.А. и др. Государственная геологическая карта Российской Федерации масштаба 1:200000. Издание второе. Серия Полярно-Уральская. Листы Q-42-I, II. Объяснительная записка. СПб. Изд-во: ВСЕГЕИ. 2007. 340 с.

2. Душин В.А., Сердюкова О.П., Малюгин А.А., Никулина И.А. и др. Государственная геологическая карта Российской Федерации. Масштаб 1 : 200 000. Издание второе. Серия Полярно-Уральская. Лист Q-42VII, VIII (Обской). Объяснительная записка. СПб.: Картографическая фабрика ВСЕГЕИ. 2014. 384 с.

3. Пыстина Ю.И., Пыстин А.М. Цирконовая летопись уральского докембрия. Екатеринбург. Изд-во: УрО РАН. $2002.168 \mathrm{c}$.

4. Уляшева Н.С., Ронкин Ю.Л. Химический состав и геодинамические обстановки формирования протолитов амфиболитов и гранатовых эклогитов марункеуского комплекса (Полярный Урал) // Известия Коми научного центра УрО РАН. 2014. № 1(17). С. 71-79.

5. Уляшева Н.С. Метаморфизм, метасоматоз и рудная минерализация пород харбейского метаморфического комплекса // Вестник Воронежского государственного университета. Серия: геология. 2019. № 1. C. $47-57$. 